$\bar{I} Q \bar{A} N$ : Vol: 01, Issue: 02, Jun 2019

\title{
THE IMPACT OF THE PROPHETIC SUNNAH ON CHARACTER BUILDING OF AN INDIVIDUAL PERSON
}

\author{
Dr. Muhammad Sarwar Hijazi \\ Assistant Professor, Islamabad Model College (Boys) \\ Islamabad, Pakistan. \\ Dr. Jamil Akhtar \\ Lecturer, Department of Islamic Studies, \\ University of Gujrat, Gujrat, Pakistan.
}

\begin{abstract}
$\underline{\text { Abstract }}$
Character building of a person is very necessary to make any society better, healthier and superior as the construction of society depends upon the people's character building. A number of crime cases are evident that the character of most people is already in alarming phase. However family members, society, Islamic schools madāris, universities, and cultural activities can play vital role in character building. Improvement in our current situation as well as development of our future depends upon the building of people character. This study aims to highlight the impact of the Prophetic Sunnah and to show its effective role in building the character of a person individual through the selection of practical models of the true Sunnah, for example, showing great care for all aspects of human such as materialistic, mental and spiritual aspects. If we really want to improve our society or turn it to perfection, people will have to focus on character building, particularly on people's moral, spiritual and social character so that society can present the real portrait of peace and prosperity. This study concluded that the Prophetic Sunnah is rich in the educational principles which preceded the contemporary research and theories, making it first reference as a basic requirement.
\end{abstract}

Keywords: Character building, Personality, Islamic Character, Personality development, Impact of Sunnah. 


\section{Introduction:}

The Sharia has given importance to human being since its creation. When the Almighty Allah created $\bar{A} d a m,{ }^{1} \mathrm{He}$ Himself regarded human with dignity $^{2}$ and asked His angels to bow their head for him. ${ }^{3}$ So, human being was preferred to other creations. ${ }^{4}$ Character building is a fertile and lively topic for researchers. The construction of the character in Islam is based on precise measurements, unlike the standards of human beings, which are dominated mostly to the narrow interests such as social class, sex, color, nationality and homeland.

Character is the name of a person's mental, physical and special behavior as well as his attitude and role. In other words the character, if it is simply defined, can be linked to man's manifest and his personal attributes, ideology, moral values as well as his actions and emotions. As Farghal said:

"It is the integrated system of a set of physical, emotional, and cognitive characteristics that determine the individual's self and distinguish him from others" 5

The explicit beauty can draw someone's attention but the eternal beauty of the character makes humans alive as Saleh said:

"It is the system full of relatively static, physical and psychological trends

that characterize an individual, and decide the distinctive ways to adapt it

with its physical and social environment" ${ }^{\prime \prime}$

Referring to our Islamic sources, we find out that character building of the individual person is considered as the tool of change in society and

\footnotetext{
${ }^{1}$ Āl-'Imrān: 59

${ }^{2}$ Al-Isrā: 70

${ }^{3}$ Al-Baqarah: 34

${ }^{4}$ Al-Isrā: 70

${ }^{5}$ Farghal, Yahya Hashim Hassan, M'ālim Shakhsiat al-Muslim, (Beirut: Manshurat al-Maktbah al-'Asriah, $1399 \mathrm{AH}), \mathrm{p}: 7$

${ }^{6}$ Saleh, Ahmed Zaki, 'Ilm al-Nafs al-Tarbaviyyi, (Cairo: Maktabah al-Nahzah al-Misriyyah, 1988), p:32
} 
the main source for the development of society. Although, Islam, no doubt, gives a lot of importance and attention to collective spirit, as it will be explained later on, and it plays its role in character building yet the process of character building is extremely personal. Ideologically, sociologically or psychologically, no such machine is discovered that can change the traits of a person into a good character. Individual's realization, self-effort, and determination can build this character. Allah Almighty makes each person individually accountable for his entire life as well as everyone will be accountable individually on the Day of Judgment. As Prophet SAW said:

$$
\begin{aligned}
& \text { "ألا كلكم راع و كلكم مسئول عن رعيته، فالإمام الذي على الناس راع وهو مسئول عن رعيته، والرجل } \\
& \text { راع على أهل بيته، وهو مسئول عن رعيته، والمرأة راعية على أهل بيت زوجها، وولده وهي مسئولة عنهم، }
\end{aligned}
$$

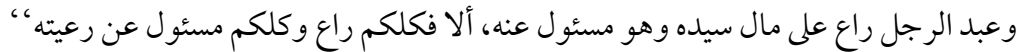

"Every one of you is a shepherd and is responsible for his flock. The leader of people is a guardian and is responsible for his subjects. A man is the guardian of his family and he is responsible for them. A woman is the guardian of her husband's home and his children and she is responsible for them. The servant of a man is a guardian of the property of his master and he is responsible for it. No doubt, every one of you is a shepherd and is responsible for his flock"l

Character building is not a piece meal or part time job. It is an unceasing, unending process, and no one can achieve it by using any shortcut within a day, week, month or year. As it is life-long process that has no end and it demands a prolonged effort so the process of character building must be subject to personal effort and endeavors. Each of us must try his best to perform this task and function. Although, the society, definitely, assists, cooperates, extends its help and makes the things easy yet everyone has to perform his process individually.

In fact, the aspects of which the Sunnah gave attention are too many but the researcher has discussed some very important aspects. These aspects directly contribute to the character building of the Muslim individual and that will make him active in his society and he does not feel inferiority and defeatism. So here are some aspects, directly deduced

\footnotetext{
${ }^{1}$ Al-Bukhārī, Muḥammad bin Ismā̄îl, Saḥịh Al-Bukhārī, (Beirut: Dār Ṭōq al-Nijāt, 1998), h: 7138
} 
The Impacts of the Prophetic Sunnah on Character Building

through the text of the Prophet, that lead to the character building:

\section{Optimism and Positive Activities:}

The Prophetic Sunnah instills in human personality optimism and positive activities that play vital role in character building, by distancing him from laziness and the negative activities. The Prophet SAW said:

$$
\begin{aligned}
& \text { "على كل مسلم صدقة. فقالو ا: يا نبي الله، فمن لم يمد؟ قال : يعمل بيده، فينفع نفسه ويتصدق. قالو ا: فإن } \\
& \text { لم يجد؟ قال: يعين ذا الحاجة الملهوف. قالو ا: فإن لم يجد؟ قال: فليعمل بالمعروف، وليمسك عن الشر، فإنها } \\
& \text { له صدقة، }
\end{aligned}
$$

"Every Muslim has to give in charity. The people then asked: But what if someone has nothing to give, what should he do? The Prophet replied: He should work with his hands and benefit himself and also give in charity from what he earns. The people further asked: If he cannot find even that? He replied: He should help the needy who appeal for help. Then the people asked: If he cannot do even that? The Prophet finally said: Then he should perform good deeds and keep away from evil deeds, and that will be regarded as charitable deeds" 1

Character can be built by performing positive activities in the society. It is also optimism that a person, instead of living an individual life, prefers to live social life, reconciles between the disputants, supports the oppressed, dominates the oppressor and develops the spirit of emotional participation in him. The community is like one body as Prophet SAW said:

بالسهر والحمى ، ، المؤمنين في تو ادهم، وتراحمهم، وتعاطفهم مثل الجسد إذا اشتكى منه عضو تداعى له سائر الجسد

"The believers in their mutual kindness, compassion and sympathy are just like one body. When any limb of it aches, the whole-body aches, because of sleeplessness and fever"

In the same scenario the Prophet SAW said:

$$
\text { "المؤمن للمؤمن كالبنيان يشد بعضه بعضا، ' }
$$

\footnotetext{
${ }^{1}$ Al-Bukhārī, Sahīh Al-Bukhārī, h h: 1445

${ }^{2}$ Muslim bin al-Hajjaj, Saḥ̆ḥ Al-Muslim, (Beirut: Dār Iḥya al-Turās al-'Arabi), ḥ: 2586
} 
"A believer to another believer is like the bricks of a building whose different parts strengthens each other" ${ }^{\prime \prime}$

In order for the Muslim to remain optimistic, the Sunnah freed his personality from all psychological pressure that could affect him, such as fear of self-refraction and contempt for grace. Abu Hurayrah R.A reported: The Prophet SAW said:

"انظروا إلى من هو أسفل منكم و لا تنظروا إلى من هو فوقكم، فهو أجدر أن لا تزدروا نعمة الله عليكم"،

"Look at the people beneath you in wealth and worldly affairs and do not gaze the ones above you in this matter. By this, you will not underestimate the bounty of Allah bestowed upon you" 2

Al Munāwī R.A describes in the explanation of this Hadith: "If someone look at the people above him in wealth and worldly affairs, he will belittle the provisions of Allah on him and he will aim for more. The way to cure such condition is to look at people beneath him in wealth and worldly affairs. Thus, he will be please and grateful, and his greed in wealth and world will be decreased. If one often looks at the people above him, he will be dissatisfied with his provisions from Allah. But if he switches his gaze to the people beneath him, it will make him please and be grateful of Allah's provisions upon him. Al Ghazali R.A said: Satan will forever try to switch men's gaze to those above him in worldly affairs. Satan will whisper to him, 'Why don't you be haste in seeking and gaining wealth, so that you can live prosperously[?]' But regarding religious matters and the Hereafter, Satan will turn his face to people beneath him in religious affairs, saying 'Why do you feel bad and humbled in front of Allah [?]' That man is still more knowledgeable than you" 3

The Sunnah also freed the person from fear of death, so he should not wish to die. As Anas R.A reported that the Prophet SAW said:

$$
\begin{aligned}
& \text { ”لا يتمنين أحدكم الموت من ضر أصابه، فإن كان لا بد فاعلا، فليقل : اللهم أحيني ما كانت الحياة خيرا }
\end{aligned}
$$

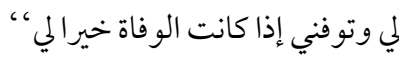

"None of you should wish for death because of a calamity befalling

\footnotetext{
${ }^{1}$ Sahīh Al-Bukhārī, ḥ: 2446

${ }^{2}$ Ahmad bin Hanbal, Musnad Ahmad bin Hanbal, (Beirut: Moassisah al-Risalah), h: 7442

${ }^{3}$ Al Munāwī, Zain ud Din Muhammad, Faị̣ al-Qadīr Sharh al-Jami' al-Saghīr, (Egypt: Al-Maktaba al-Tajjaria al-Kubra, $1356 \mathrm{AH}), 3: 59$
} 
him; but if he has to wish for death, he should say: "O Allah! Keep me alive as long as life is better for me, and let me die if death is better for me"l

The Prophetic Sunnah also freed him from fear of a livelihood as it is narrated by Jabir bin 'Abdullah R.A that Prophet SAW said:

$$
\begin{aligned}
& \text { "أيها الناس اتقوا الله وأجملو في الطلب، فإن نفسا لن تموت حتي تستوفي رزقها وإن أبطأ عنها، فاتقو الله }
\end{aligned}
$$

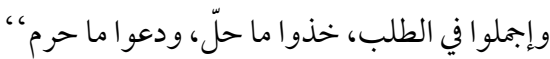

"O people, fear Allah and be moderate in seeking a living, for no soul will die until it has received all its provision, even if it is slow in coming. So fear Allah and be moderate in seeking provision; take that which is permissible and leave that which is forbidden" ${ }^{2}$

Such a positive spirit and good character instilled in the personality of the Muslim individual will bring peace and happiness to himself, and then move on to the society to make this individual a productive performer.

\section{Moderation (Wastia) in Worship:}

Moderation in worship means that one does not cross the limit set by Allah Almighty and described by His beloved Prophet SAW, as well as one does not try to do more than Prophet SAW did. Allah Almighty says: "And thus we have made you a just community that you will be witnesses over the people and the Messenger will be a witness over you. And we did not make the qiblah which you used to face except that we might make evident who would follow the Messenger from who would turn back on his heels. And indeed, it is difficult except for those whom Allah has guided. And never would Allah have caused you to lose your faith. Indeed Allah is, to the people, Kind and Merciful." ${ }^{13}$ Moderation Wastia is the most eminent characters in this true religion, and moderation means that one side is equivalent to the other one i.e. there is no immoderation, extremism, exaggeration, high-handedness, delinquency, transgression, depreciation or underestimation; yet, each side takes its right by righteous measures.

\footnotetext{
${ }^{1}$ Sahīh Al-Bukhārī h: 5671

${ }^{2}$ Ibn Majah, Muhammad bin Yazī̄d, Sunan Ibn Majah, (Beirut: Dār al-Risālah al-'Ālmia), ḥ: 2144

${ }^{3}$ Al-Baqarah: 143
} 
$\bar{I} Q \bar{A} N$ : Vol: 01, Issue: 01, Dec 2018

The Prophetic Sunnah, in its construction of the Muslim character, worked to take account of the physical and mental differences as well as the spiritual readiness, and ordered the facilitation and non-exaggeration in worship otherwise individual may eventually be led to the abandonment of work. 'Abdullah bin 'Amr R.A narrated: The Prophet SAW said:

$$
\text { "أحب الصيام إلى الله صيام داود، كان يصوم يو ما ويفطر يوما، وأحب الصلاة إلى الله صلاة داود، كان }
$$

"The most beloved fasting to Allah was the fasting of the Prophet David who used to fast on alternate days. And the most beloved prayer to Allah was the prayer of David who used to sleep for the first half of the night and pray for one third 1/3 of it and again sleep for a sixth of $i t^{\prime \prime}$

When Prophet SAW came to know that 'Abdullah bin 'Amr R.A is not moderating in his worship, he said:

$$
\text { و "يا عبد الله، ألم أخبر أنك تصوم النهار وتقوم الليل؟ قلت : بلى يا رسول الله، قال : فلا تفعل، صم وأفطر، }
$$

"O 'Abdullah! Have I not been formed that you fast all the day and stand in prayer all night? I said, Yes, O Allah's Apostle! He said, Do not do that! Observe the fast sometimes and also leave them the fast at other times; stand up for the prayer at night and also sleep at night. Your body has a right over you, your eyes have a right over you and your wife has a right over you"'

Abu Juhaifa R.A narrated that the Prophet SAW made Salman R.A and Abu Ad-Darda' R.A brothers after Hijrah. One day Salman came to see Abu Ad-Darda'... He prepared a meal for Salman. He requested Abu AdDarda' to eat with him, but he said, I am fasting. Salman said, I will not eat unless you do. So, Abu Ad-Darda'ate with him. When the night appeared and a part of it passed, Abu Ad-Darda' got up for night prayer, but Salman told him to sleep. After sometime Abu Ad-Darda' again got up but Salman asked him to sleep again. When the night was in its last hours, then Salman asked him to get up, and they both offered night prayer. Salman told Abu Ad-Darda':

\footnotetext{
${ }^{1}$ Al-Bukhārī, Sahịh Al-Bukhārī, ḥ: 3420

${ }^{2}$ Ibid, h: 5199
} 
The Impacts of the Prophetic Sunnah on Character Building

$$
\begin{aligned}
& \text { ” إن لربك عليك حقا، ولنفسك عليك حقا، ولأهلك عليك حقا، فأعط كل ذي حق حقه، فأتى النبي } \\
& \text { صلى الله عليه وسلم، فذكر ذلك له، فقال النبي صلى الله عليه وسلم: صدق سلمان، ، }
\end{aligned}
$$

"Your Lord has a right on you, your soul has a right on you, and your family has a right on you; so you should give the rights of all those who has a right on you. Abu Ad-Darda' came to the Prophet and narrated whole story. Prophet said, Salman has spoken truth" 1

It is also moderation in worship to not keep the sermons due to the fear of boredom and tiredness of people as Abdullah bin Mas`ud R.A narrated:

$$
\text { "كان النبي صلى الله عليه وسلم يتخولنا بالمو عظة في الأيام، كراهة السآمة علينا، ، }
$$

"The Prophet used to take care of us in preaching by selecting a suitable time, so that we might not get bored. He abstained from pestering us with sermons and knowledge all the time" ${ }^{2}$

Abu Wail narrated that 'Abdullah used to give a piece of religious talk to the people on every Thursday. One day a man requested, $\mathrm{O}$ Abdullah! By Allah I wish if you could preach us daily. He replied:

$$
\text { "أما إنه يمنعني من ذلك أني أكره أن أملكم، وإني أتخولكم بالموعظة، كما كان النبي صلى الله عليه وسلم }
$$

"The only thing which prevents me from doing so, is that I hate to bore you, and no doubt I take care of you in preaching by selecting a suitable time just as the Prophet used to do with us, for fear of making us bored" ${ }^{3}$

Ibn Hajar R.A said in the explanation of this Hadith: This Hadith indicates that: it is better to leave the regularity even in the good work due to the fear of boredom. If the regularity in any work is required it may be divided into two parts: either perform it every day with no affectation or do it day after day. ${ }^{4}$

\footnotetext{
${ }^{1}$ Al-Bukhārī, Saḥịh Al-Bukhārī, ḥ: 1968

2 Ibid, ḥ: 68

${ }^{3}$ Ibid, h: 70

${ }^{4}$ Ibn Hajr, Ahmed bin 'Ali, Fath al-Bārī, (Beirut: Dār al-Ma'rifah), 1:163
} 
Islam does not want the believers to conquer their material humanism as well as it does not encourage them to leave the worldly life and the best of the living. Islam is fully against the Monasticism that isolates the religion from human worldly life because Islam is a moderate Wastia religion. It is the best example in which Ans bin Malik narrated that three men came to the houses of Prophet's wives and ask how the Prophet worships Allah, and when they were informed about that, they considered their worship insufficient and said:

$$
\begin{aligned}
& \text { "وأين نحن من النبي صلى الله عليه وسلم؟ قد غفر له ما تقدم من ذنبه وما تأخر، قال أحدهم: أما أنا } \\
& \text { فإني أصلي الليل أبدا، وقال آخر: أنا أصوم الدهر ولا أفطر، وقال آخر: أنا أعتزل النساء فلا أتزوج أبدا، } \\
& \text { فجاء رسول الله صلى الله عليه وسلم إليهم، فقال: أنتم الذين قلتم كذا وكذا، أما والله إني لأخشاكم لله }
\end{aligned}
$$

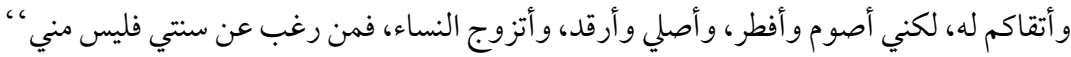

"Where are we from the Prophet as his past and future sins have been forgiven. Then one of them said, I will offer the prayer throughout the night forever. The other said, I will fast throughout the year and will not break my fast. The third said, I will keep away from the women and will not marry forever. Allah's Apostle came to them and said, Are you the same people who said so-and-so? By Allah, I am more submissive to Allah and more afraid of Him than you; yet I fast and break my fast, I do sleep and I also marry women. So he who does not follow my tradition in religion, is not from me not one of my followers" ${ }^{1}$

This Hadith clearly indicate that the Prophet PBUH did not encourage if someone leaves the worldly deeds and spares himself just for worship. Moderation in worship and everything builds a balanced human character that is required by Islam.

\section{Self-esteem and Self-respect:}

Another character building source is Self-esteem. It, in psychological context, is a personal assessment designated by the attitude held by someone about himself. It is a one-sided experience expressed to others through behavior and speech... as well as self-esteem is a feeling of selfrespect, self-admiration and self-regard. ${ }^{2}$ The Prophetic Sunnah urged the

\footnotetext{
${ }^{1}$ Sahīh Al-Bukhārī, ḥ: 5063

${ }^{2}$ Coopersmith, Stanley (Ed.), The Antecedents of Self-esteem, (CA: W. H. Freeman), p:8
} 
Muslim individual to be self-esteem and not to rely on humiliation and misery, as Al-Zubair bin Al-'Awwam R.A narrated that the Prophet SAW said:

$$
\begin{aligned}
& \text { ”لأن يأخذ أحدكم حبله، فيأتي بحزمة الحطب على ظهره، فيبيعها، فيكف اله بها وجهه خير له من أن }
\end{aligned}
$$

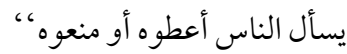

"It is better for anyone of you to take a rope and cut and bring a bundle of wood from the forest over his back and sell it and Allah will save his face from the Hell-Fire because of that, rather than to ask the people who may give him or not"l

This hadith is supported by an incident that is narrated by 'Urwa bin Al-Zubair R.A and Sa id bin Al-Musaiyab R.A that Hakim bin Hizam R.A said:

$$
\begin{aligned}
& \text { " بألت رسول الله صلى اله عليه وسلم، فأعطاني، ثم سألته، فأعطاني، ثم سألته، فأعطاني ثم قال: (يا }
\end{aligned}
$$

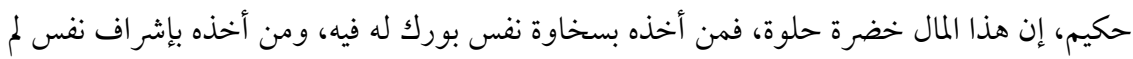

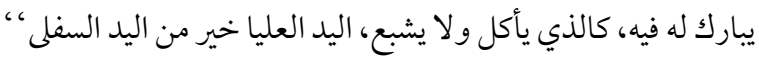

"Once I asked Allah's Prophet SAW for something and he gave it to me. Again I asked and he gave it to me. Again I asked and he gave it to me. And then he said, O Hakim! This property is like a sweet fresh fruit; whoever takes it without greediness, he is blessed in it, and whoever takes it with greediness, he is not blessed in it, and he is like a person who eats but is never satisfied; and the upper giving hand is better than the lower receiving hand"

Hakim added, I said to Allah's Prophet SAW, 'By Him Allah Who sent you with the Truth, I shall never accept anything from anybody after you, till I leave this world. Then Abu Bakr R.A called Hakim during his caliphate to give him his share from the war booty like the other companions of the Prophet, he refused to accept anything. Then 'Umar R.A called him during his caliphate to give him his share but he refused. On that 'Umar R.A said, O Muslims! I would like you to witness that I offered Hakim his share from this booty and he refused to take it. So, Hakim never

\footnotetext{
${ }^{1}$ Saḥịh Al-Bukhārī, ḥ: 1471
} 
took anything from anybody after the Prophet SAW till he died."

The companions of Prophet SAW applied this self-righteous in their practical life even if the whip of anyone of them fell down they did not ask anyone else to pick up it for them. ${ }^{2}$

As Majid 'Arsan al-Kilani said: "The Muslim individual is the man who does the righteous work, because the good work is the cause of creation and finding, which is the subject of asceticism and testing in this life and is a measure of success in hereafter life. No one can imagine that a good character can be built without moral deeds. It is not piety and Taqwa to leave doing good deeds. These are just some characteristics of good work earned by character and these traits distinguish a man from the bad work." ${ }^{13}$

This point indicates that a person's self-respect is very important in building his character.

\section{Freedom to Ask the Questions:}

The purified Sunnah followed, for character building, a unique approach in allowing questions to be released in order to come into being. The Companions had questions about some of the issues, but they were afraid to reveal them, fearing that they would affect their faith or they will be considered as unwise. Neither the best teacher of the world our Prophet SAW suppressed these questions nor his chest was narrowed by any question. Even he did not refrain from answering any question so that these questions would not remain locked.

He SAW encouraged them to reveal their queries in regard to any issue and then guided them to the correct answer. He usually used to sit in Masjid, people come and ask him about different things such as Anas bin Malik narrated: "While we were sitting with the Prophet in the mosque, a man came riding on a camel. He made his camel kneel down in the mosque, tied its foreleg and then said:

Who amongst you is Muhammad? At that time the Prophet was sitting amongst us his companions leaning on his arm. We replied, This white man reclining on his arm. The man then addressed him, O Son of 'Abdul Muttalib. The Prophet said, I am here to answer your questions. The

${ }^{1}$ Al-Bukhārī, Saḥịh Al-Bukhārī, ḥ: 1472

2 Sahīh Al-Muslim, h: 2403

${ }^{3}$ Al-Kilani, Majid 'Arsan, Goals of Islamic Education, (UAE: Dar al-Qalam), p:41 
man said to the Prophet, I want to ask you something and will be hard in questioning. So do not get angry. The Prophet said, Ask whatever you want. The Prophet replied his every question. Thereupon that man said, I have believed in all that with which you have been sent, and I have been sent by my people as a messenger, and I am Dimam bin Tha laba from the brothers of Bani Sa 'd bin Bakr." ${ }^{11}$ That person embarrassed Islam and returned to his people with the blessing of Islam. The Prophet SAW always replied to every question and never discouraged the questions raised by his companions such as Abdullah bin Mas'ud R.A narrated:

$$
\text { قلت "سألت رسول الله صلى اله عليه وسلم قلت: يا رسول الله، أي العمل أفضل؟ قال: الصلاة على ميقاتها. }
$$

"I asked Allah's Prophet, O Allah's Apostle! What is the best deed? He replied, To offer the prayers at their early stated fixed times. I asked, What is next in goodness? He replied, To be good and dutiful to your parents. I further asked, what is next in goodness? He replied, To participate in Jihad in Allah's Cause. I did not ask Allah's Apostle anymore and if I had asked him more, he would have told me more" 2

Sometimes the Prophet SAW answered to the questioner in addition to his answer, he added it in the answer to cover all the aspects of topic. As Abu Hurairah narrated:

$$
\begin{aligned}
& \text { "سأل رجل رسول الله صلى الله عليه وسلم، فقال: يا رسول الله، إنا نركب البحر ونحمل معنا القليل من } \\
& \text { الماء، فإن توضأنا به عطشنا، أفنتوضأ من ماء البحر؟ فقال رسول الله صلى الله عليه وسلم: هو الطهور }
\end{aligned}
$$

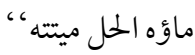

"A man asked the Prophet SAW: O Messenger of Allah, we travel by sea and we take a little water with us, but if we use it for Wudu', we will go thirsty. Can we perform Wudu', with sea-water?' The

\footnotetext{
${ }^{1}$ Al-Bukhārī, Sahīh Al-Bukhārī, h: 63

${ }^{2}$ Ibid, h: 2782
} 
$\bar{I} Q \bar{A} N$ : Vol: 01, Issue: 01, Dec 2018

Messenger of Allah SAW said: Its water is a means of purification and its dead meat is permissible"l

Muhammad Ashraf Azim al-Abadi said in the explanation of this Hadith, if the mufti is asked about something, and he is aware that the questioner also needs to be taught some extra answer that is related to his question, he is well advised to teach it, because the increase in the answer "its dead meat is permissible", is for the completion of questioner's interest. This increase in answer was in benefit to the fishing people and the questioner was one of them. So, this is the real merit of fatwa. ${ }^{2}$

\section{To Take Account of the Ethics with Others:}

Islam consists on beliefs that must apparent in a set of rituals and that rituals must have an impact on the character building of an individual person. These characteristics manifest themselves at the time of dealing with others. If one is performing the worship with an excellent way but he is not good by character then his worship will not fulfill the deficiency of his character. However if someone is excellent in his character then it may make up for the deficiency of worship. The Prophetic Sunnah has always taken care of the interests of others regardless of their status, as well as the interest of the person himself. Everyone should be polite with others and to not disturb them by any means, although by using any easy way, even if it is unpleasant smell coming from the one's mouth. The Pophet SAW said:

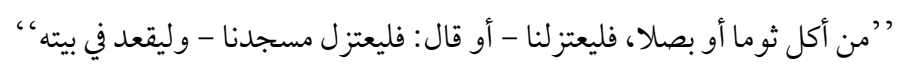

"Whoever eats garlic or onion should keep away from our mosque or should remain in his house"

It is also ethic to take care the rights of others as the Prophet SAW did, Sahl bin Sa`d R.A narrated:

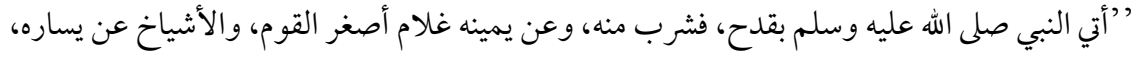

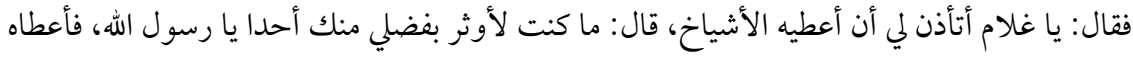

$$
\begin{aligned}
& \text { إياه؛ }
\end{aligned}
$$

\footnotetext{
${ }^{1}$ Abu Daud, Sulaiman bin al-Ash'as, Sunan Abi Daud, (Beirut: al-Maktabah al-'Asria), ḥ: 83

${ }^{2}$ Azim al-Abadi, Muhammad Ashraf bin Amir bin Ali, Aun al-Ma'bud, (Beirut: Dār al-Kutub al-'Ilmia, 1415), 1:107

${ }^{3}$ Al-Bukhārī, Saḥ̄ḥ Al-Bukhārī, ḥ: 855
} 
The Impacts of the Prophetic Sunnah on Character Building

"A tumbler full of milk or water was brought to the Prophet who drank from it, while on his right side there was sitting a boy who was the youngest of those who were present and on his left side there were old men. The Prophet asked, O boy, will you allow me to give it i.e. the rest of the drink to the old men? The boy said, O Allah's Prophet! I will not give preference to anyone over me to drink the rest of it from which you have drunk. So, the Prophet gave it to him"l $^{\prime \prime}$

The Prophetic Sunnah also takes care of the interests of servants, whom no one would ever pay attention to. Abu Huraira R.A narrated: The Prophet SAW said:

$$
\text { " إذا أتى أحدكم خادمه بطعامه، فإن لم يجلسه معه، فليناوله أكلة أو أكلتين، أو لقمة أو لقمتين، فإنه ولي }
$$

"When your servant brings your food to you, if you do not ask him to join you, then at least ask him to take one or two handfuls, for he has suffered from its heat while cooking it and has taken pains to cook it nicely" ${ }^{2}$

No other religion teaches its follower such good manners as Islam does. The Prophet SAW of Islam values the human soul even if it is not the soul of a Muslim. Such incidents help a lot to build the character. 'Abdur Rahman bin Abi Laila Narrated: Sahl bin Hunaif R.A and Qais bin Sa 'd R.A were sitting in Al-Qadisiya city. A funeral procession passed in front of them and they stood up. They were told that funeral procession was of one of the inhabitants of the land i.e. of a non-believer, under the protection of Muslims. They said:

$$
\text { "إن النبي صلى الله عليه وسلم مرت به جنازة فقام، فقيل له: إنها جنازة يهو دي، فقال : أليست نفسا، }
$$

"A funeral procession passed in front of the Prophet and he stood up. When he was told that it was the coffin of a Jew, he said, Is it not a living being soul?"3

\footnotetext{
${ }^{1}$ Al-Bukhārī, Saḥ̄h Al-Bukhārī, ḥ: 2351

2 Ibid, h: 5460

${ }^{3}$ Ibid, h: 1312
} 
$\bar{I} Q \bar{A} N:$ Vol: 01, Issue: 01, Dec 2018

It is also considered as to take account of ethics with others that; two people should not hold secret counsel together excluding the third, one should keep the secret of others as well as one should not sit at his brother's place as the Prophet SAW said:

$$
\text { " لا يقيم الرجل الرجل من مجلسه ثم يجلس فيه" }
$$

"A man should not make another man get up from his the latter's seat in a gathering in order to sit there" 1 building:

Here are some other Prophetic Sunnah that play its role in Character

\section{Treat the People with Love, Care and Kindness:}

The Prophetic Sunnah teaches us how to treat the people? How can we build and develop our character. The most important thing in this regard is to treat the people as we would love to be treated by people. 'Abdullah bin 'Amr R.A reported that the Prophet SAW said:

$$
\text { ما يمب أن يوتي إليه، ، ئح عن النار ويدخل الجنة فلتدركه منيته وهو يؤمن بالهة واليوم الآخر ويأتي إلى الناس }
$$

"Whoever would love to be saved from the Hellfire and entered into

Paradise, then let him die with faith in Allah and the Last Day, and let him treat the people the way he would love to be treated"2

Sunnah also teaches us if someone takes care of us we must be thankful to him. As Abu Huraira R.A reported that the Prophet SAW said:

$$
\text { ” الا يشكر الله من لا يشكر الناس" }
$$

"He has not thanked Allah who has not thanked people"3

Sunnah tells us we must treat the people in a good way and people feel themselves safe due to us as Abu Huraira R.A reported that the Prophet SAW said:

$$
\text { "المسلم من سلم الناس من لسانه ويده، والمؤمن من أمنه الناس على دمائهم و أمو الهم"، }
$$

${ }^{1}$ Al-Bukhārī, Sahīh Al-Bukhārī, h: 6269

2 Sahīh Al-Muslim, h: 1844

${ }^{3}$ Sunan Abi Daud, ḥ: 4811 
The Impacts of the Prophetic Sunnah on Character Building

"The Muslim is the one from whose tongue and hand the people are safe, and the believer is the one people trust with their lives and wealth $^{\prime \prime}$

Even if someone is in the state of anger Sunnah guide us to maintain our character and forgive others as Abu Huraira R.A reported that the Prophet SAW said:

$$
\text { "ليس الشديد بالصرعة، إنما الشديد الذي يملك نفسه عند الغضب" }
$$

"The strong are not the best wrestlers. Verily, the strong are only those who control themselves when they are angry"

Sunnah clearly mentioned if someone will not show mercy on others he will be not shown mercy by Allah Almighty as 'Abdullah ibn 'Amr reported that the Prophet SAW said:

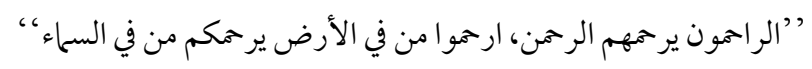

"Those who are merciful will be shown mercy by the Most Merciful. Be merciful to those on the earth and the One in the heavens will have mercy upon you" ${ }^{\prime 3}$

The Prophet SAW was very kind to people even when he was said: "O Messenger of Allah, pray against the idolaters!" The Prophet SAW said:

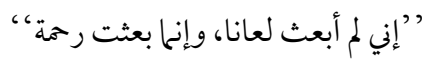

"Verily, I was not sent to invoke curses, but rather I was only sent as mercy"

It is not just the trait of Prophet Muhammad SAW but even the attributes of Allah Almighty as 'Aisha R.A reported that the Prophet SAW said:

$$
\text { "إن الهَ رَفيق يجب الرفق، ويعطي علي الرفق ما لا يعطي علي العنف وما لا يعطي على ما سواه"، }
$$

"Verily, Allah is kind and he loves kindness. He rewards for kindness what is not granted for harshness and he does not reward

\footnotetext{
${ }^{1}$ Al-Nasā̄'̄ , Ahmed bin Shoaib, Sunan al-Nasā' ’̄, (Halab: Maktab al-Matbuat al-Islamia), ḥ: 4995

${ }^{2}$ Sahīh Al-Bukhārī, ḥ: 1312

${ }^{3}$ Al-Tirmidhī, Muhammad bin 'Isa, Sunan al-Tirmidhī, (Beirut: Dār al-Gharb al-Islami), ḥ:1 924

${ }^{4}$ Saḥ̄h Al-Muslim, ḥ: 2599
} 
$\bar{I} Q \bar{A} N$ : Vol: 01, Issue: 01, Dec 2018

anything else like it" ${ }^{\prime \prime}$

Allah Almighty is very kind to people regardless he is Muslim or not. Muslims should also try to be characterized with the attributes of Allah Almighty.

In this way we can see the clear impact of Prophetic Sunnah on Character Building of an Individual Person. These are some of the characteristics of Prophet Muhammad PBUH that bring respect and admiration to him in both the Islamic and non-Islamic circles. He, no doubt, has the best character. The lines above discuss some major character traits of Prophet Muhammad PBUH that every Muslim should implement in their lives as much as they can.

\section{Conclusion:}

This research paper concluded that the Prophet Sunnah emphasized the issues of individuals in order to building their characters. This research papers demonstrates that a healthy society is possible just because of the character building of the individuals. This research paper concluded that:

The Prophetic Sunnah plays a vital role in character building of people. Character building is more important than house building. There are a lot of western theories in regard to education and psychology that are attributed to western thinkers these have roots and origins in the Prophetic Sunnah.

\section{Recommendations:}

1. On the bases of above findings, discussion and conclusion, it is recommended that:

2. Parents must play their role in character building of their children.

3. Teachers must have to change their teaching techniques in accordance with the modern time.

4. Islamic studies' teachers must be bound to get professional education to implement new teaching techniques for students' character building.

5. Islamic scholars can play their role by delivering the teachings in regard to character building in their Friday sermons.

${ }^{1}$ Sahịhh Al-Muslim, ḥ: 2593 
6. No one should underestimate himself and he must share his part in his own character building and his subordinates for the betterment and development of society.

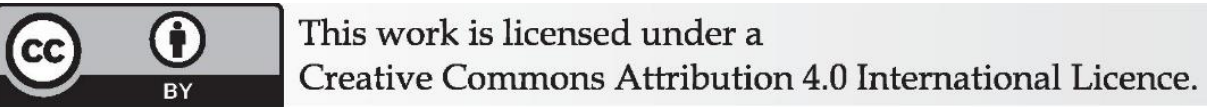

